\title{
Spring warming period of Polish lake waters in a yearly thermal cycle
}

\author{
Rajmund Skowron \\ Department of Hydrology and Water Management, Nicolaus Copernicus University, Lwowska 1, 87-100 Toruń, Poland, \\ e-mail: rskowron@umk.pl
}

\begin{abstract}
The study describes thermal regimes of thirty selected Polish lakes in the spring season. The author used 35-year series of daily measurements of surface water temperature in the years 1961-2005 and the measurements of the vertical distribution of water temperature taken in tens of selected water bodies. The diversified pace of the increase in surface water temperature (SWT) during the spring warming period makes it possible to distinguish two thermal phases: the early and late phases of spring warming. The limits of those phases are marked by the dates of the disappearance of ice cover and the dates when the SWT stays well over the threshold values, which amount to $4^{\circ} \mathrm{C}$ and $15^{\circ} \mathrm{C}$ respectively. The SWT increase in the lakes (April and May) causes changes in the water's vertical thermal structure (the formation of epi- and metalimnion) and considerable dynamics of its descriptive parameters, such as water temperature, thermal stratification coefficient, thermal gradients, heat resources, etc.
\end{abstract}

Key words: temperature of water, lakes, spring season.

\section{Introduction}

Four thermal periods are distinguished most frequently in the yearly cycle of surface water temperature (SWT) fluctuations in lakes located in temperate geographical latitudes: spring, summer, autumn and winter. Their sequencing indicates a close relation to the natural seasonal course of climatic conditioning. The spring period comprises mainly the time from March to May, the summer period from June to $\mathrm{Au}$ gust; the autumn period spans from September to November, and the winter period lasts from December to February (Chojnowski 1967; Grześ 1974). However, having analysed the daily values of surface water temperature and the courses of ice phenomena in 28 lakes located in the Polish Lowland in the years 1961-2005, Skowron $(2001,2007 a, 2011$ a) proposed a more detailed classification by differentiating between the following: a winter period with a winter cooling phase and with a winter warming phase, a spring period with an early and late spring warming phase, a summer period with a summer warming phase and with a summer cooling phase, and an autumn period with a first and second autumn cooling phase. This classification clearly corresponds to the thermal seasons in lakes located in the temperate zone, which includes the areas of the European part of Russia (Tikhomirov 1980).

The beginning of the period of spring warming of lake waters starts during the ice cover. At the end of the ice cover, just after it disappears there is a change in the resultant direction of the stream of heat between the lake and its surrounding. On average, from mid February we can observe a slow increase in water, particularly surface water, temperature in all the lakes. Jędrasik (1985), Janiec and Turczyński (1988) and Skowron's (2007b, 2011b) observations prove this phenomenon. At that time there is a relatively small increase in temperature just under the ice cover and water convection movements occur leading to water cloudiness.

On the other hand, the end of the spring period is marked by the date of the stable transition of the surface water temperature over the threshold value of $15^{\circ} \mathrm{C}$. The observations of water temperature conducted in many Polish lakes showed that a well- 
defined three-layer thermal structure develops above this value. In addition, further transformations of this regime lead to a systematic and slow deepening of the position of the metalimnion (Skowron 2011a).

The study aims to show regional differences in the course of water temperature in Polish lakes in the spring season, which correspond to the duration of the thermal periods, parameters and thermal indicators and the pace of temperature changes discussed both in the context of SWT transformation and its vertical distribution in the period 1971-2005.

\section{Material and methods}

The analysis of the materials included in this study was based upon two types of data concerning water temperature in lakes of the Polish Lowland. The primary material comprises daily values of the surface water temperature (SWT) from 30 lakes in the period 1961-2005. These data concern the SWT recorded at the depth of $0.4 \mathrm{~m}$ in the littoral part of the lake at 7:00 (6:00 GMT) every day. These measurements were carried out within the observation network of the Institute of Meteorology and Water Management. On the other hand, the measurements of the vertical distribution of water temperature in the lakes which represent the various regions of the Polish Lowland were conducted during expeditions. They were carried out in selected lakes in the years 1971-2010 by the Voivodeship Inspectorate for Environmental Protection (VIEP) and the author himself. The measurements of water temperature conducted by the particular units of the VIEP were most frequently sited in lake kettles, and water temperature was recorded every $1.0 \mathrm{~m}$ by means of the WTW thermal and oxygen sensor. In the early 1970s, the author took measurements by means of thermoelectric thermometers and recorded temperature at several points on the lake every $0.5 \mathrm{~m}$ to the depth of $15 \mathrm{~m}$, and every $1.0 \mathrm{~m}$ below that depth.

Moreover, three series of synchronous measurements in the different phases of spring warming were carried out in different lakes of the Polish Lowland. The measurements were narrowed down to three days, and involved most frequently the measurement at the deepest point of the lake. The first series was taken in late March (20-22.03) 1996, and involved 26 lakes; the second series comprised 31 lakes in the period 22-24.04.2003; and the third series covered 32 lakes in early May (7-9.05) 2000. Each of those series was carried out approximately one month after the ice cover break-up.

The measurements of the vertical distribution of water temperature carried out by means of thermal gradient sensors were also of a special character (Choiński and Kanikowski 2004; Glazik et al. 2006; Choiński 2010; Skowron 2011a). They involved registering water temperature in the invariable and deepest point of the lake at 8 levels with the frequency of 24 measurements a day. The examinations were performed in the years 2005-2007 and they comprised three lakes representing different parts of the Polish Lowland: Lake Bachotek (Brodnica Lakeland), Lake Ostrowite (Tuchola Forest) and Lake Starokiejkuckie (Mrągowo Lakeland). These water bodies show clear differences with respect to their morphometric properties, dynamic and trophic features. Altogether, 7.5 thousand records of water temperature were taken in these lakes, which constitutes very original and very important comparative material.

All the statistic calculations were carried out in Excel and Corel Quatro Pro 8, while graphic work was presented using Corel Draw 9 software.

\section{Results}

Regardless of their area, depth ratios, hydrological character and the type of mixing, the lakes of the temperate zone show seasonal changeability of water temperature. The sinusoid course of water temperature during a year is preserved in the surface layer up to the thickness of some metres (Skowron 2011a). This layer is the most sensitive element of the lake system, vulnerable to changes in meteorological conditioning. It is where all the basic processes and mechanisms occur, which then all influence the system's dynamics and regime (Choiński 2007).

Course of surface water temperature in lakes. Once the ice cover disappeared on the lakes, the SWT values were slightly higher with respect to the yearly minimum, which was recorded most frequently at the turn of January and February (Skowron 2011a). The temperature values presented in Table 1 show considerable variations among the lakes. These differences amounted to between 1.9 and $2.3^{\circ} \mathrm{C}$ on average, yet their values stayed within the range $1.32-2.95^{\circ} \mathrm{C}$.

Together with the ice cover break-up the water bodies enter the period of spring warming (Chomskis 1969; Choiński 2007; Skowron 2001, 2003, 2006, 2007b, 2011a). Due to the diverse pace of changes in water temperature and the transition of water temperature 
Table 1. Average temperatures of surface water $(0.4 \mathrm{~m})$ at the moment of occurrence of the particular glaciation phases in the analysed lakes in the period of 1961-2005 (after Skowron 2011a, partially modified)

\begin{tabular}{lcc}
\hline \multirow{2}{*}{ Lake } & \multicolumn{2}{c}{ End of } \\
\cline { 2 - 3 } & ice cover & ice phenomena \\
\hline Lubie & 2.95 & 3.08 \\
Sławskie & 2.20 & 2.61 \\
Gardno & 1.44 & 2.10 \\
Łebsko & 1.86 & 2.43 \\
Charzykowskie & 1.63 & 2.17 \\
Raduńskie G. & 2.80 & 3.42 \\
Gopło & 2.29 & 2.85 \\
Jeziorak & 2.33 & 2.64 \\
Mikołajskie & 1.38 & 2.35 \\
Nidzkie & 2.08 & 3.08 \\
Hańcza & 1.32 & 1.73 \\
Studzieniczne & 2.47 & 2.82 \\
\hline
\end{tabular}

over the value corresponding to the temperature of its greatest density, the author distinguishes the early and late phases of spring warming in this period.

The early phase of spring warming of waters begins before the complete ice cover break-up on the lakes. The mean ice-out dates showed considerable regional diversity, oscillating on average between 5 th and 9th March in the regions to the west of the River
Vistula and between 12th and 18th March in the areas located to the east of the Vistula. In this phase relatively insignificant increases in surface water temperature can be noticed between ten-day periods. These amounted to between 0.1 and $0.3^{\circ} \mathrm{C}$ per every ten-day period (Fig. 1).

Figure 2 shows an example of differences in the SWT between two lakes located in different climatic regions of Poland. They differ with respect to their thermal types, depth ratios, mixing types and water transparency (Skowron 2011a). The course of the mean daily temperature values indicates plainly that the SWT was higher in Lake Bachotek throughout the entire period. In both these cases the rhythm of temperature changeability was comparable. The mean yearly water temperature in the surface layer was similar in the multi-year period 1971-2005. It equalled $10.24^{\circ} \mathrm{C}$ in Lake Bachotek, whereas it was merely $8.42^{\circ} \mathrm{C}$ in Lake Hańcza.

The analysis of the mean daily water temperature values in the spring months (March-May) in individual years between 1971 and 2005 clearly showed considerable diversity of SWT between the years. Particularly large differences of SWT occurred between 1980 and 2000 (Fig. 3). Extremely low values of water temperature were recorded in the spring of 1980 , while in the entire study period the warmest waters in this season were those registered in 2000 (Skowron 2008).

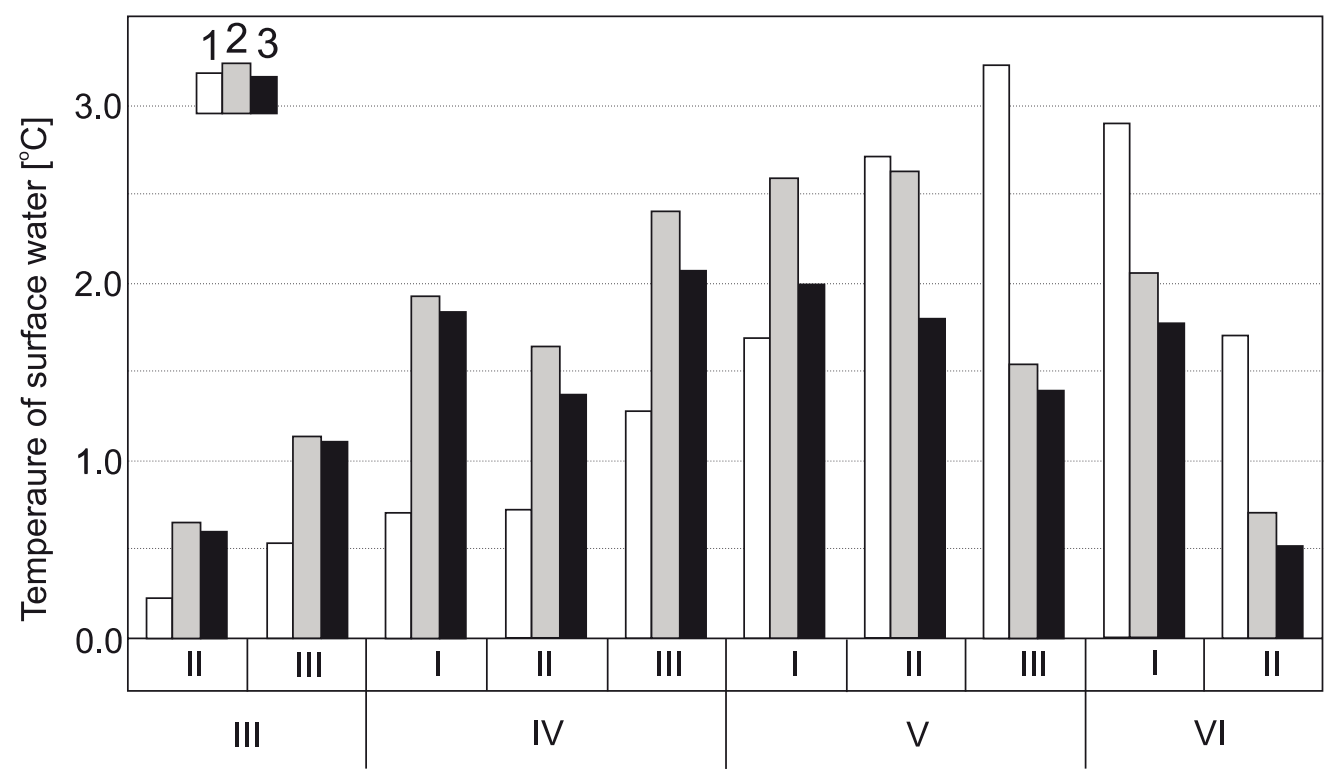

Fig. 1. Mean decade values of temperature surface water increase in the spring season in the period 1961-2005: 1 - Hańcza, 2 - Jeziorak, 3 - Łebsko (after Skowron 2011b) 


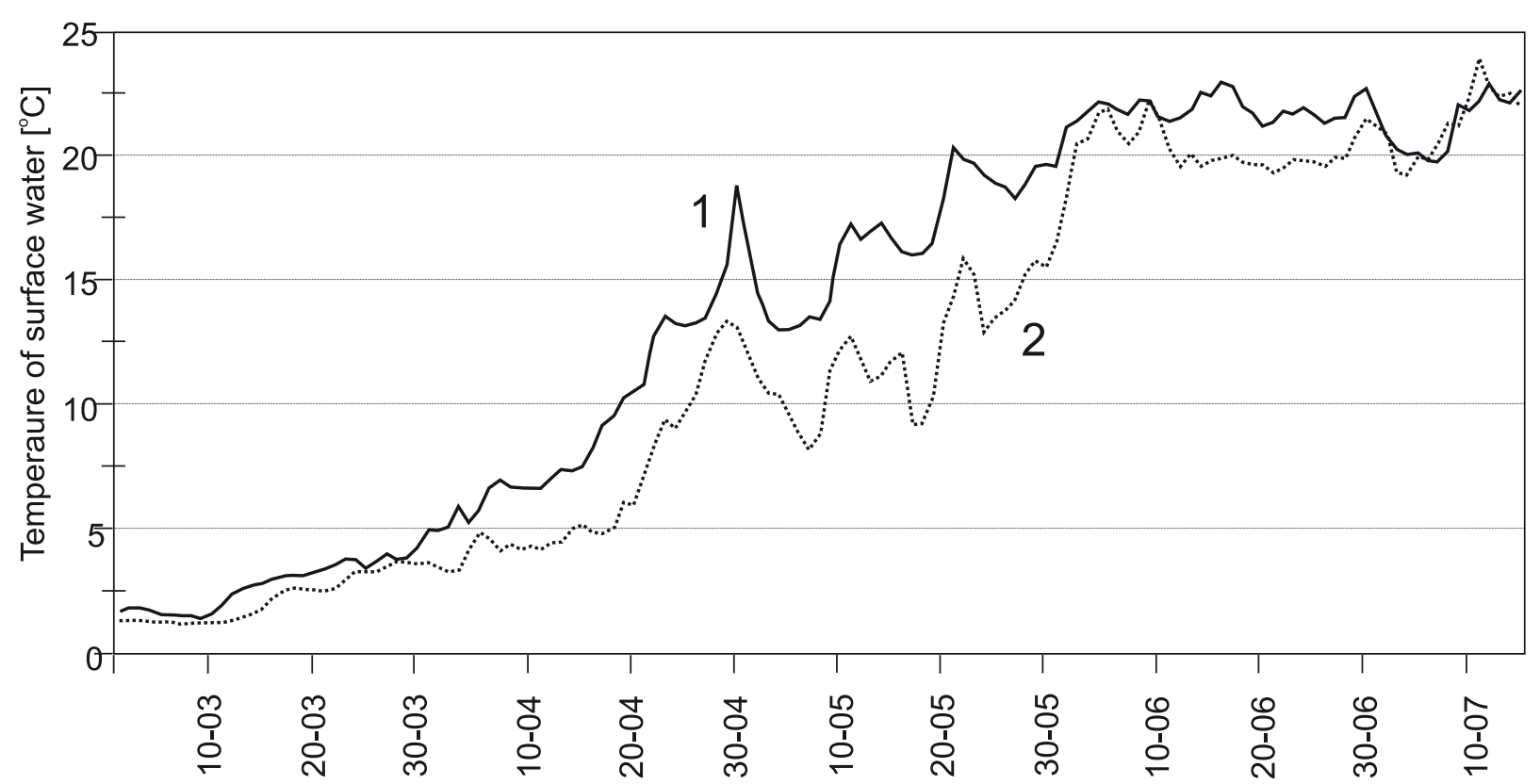

Fig. 2. The course of mean daily values of the surface water temperature $(0.5 \mathrm{~m})$ in lakes: 1 - Bachotek, 2 - Hańcza, from the beginning of March to mid-July 2011 (the daily mean value was calculated on the grounds of the hourly measurements of temperature)

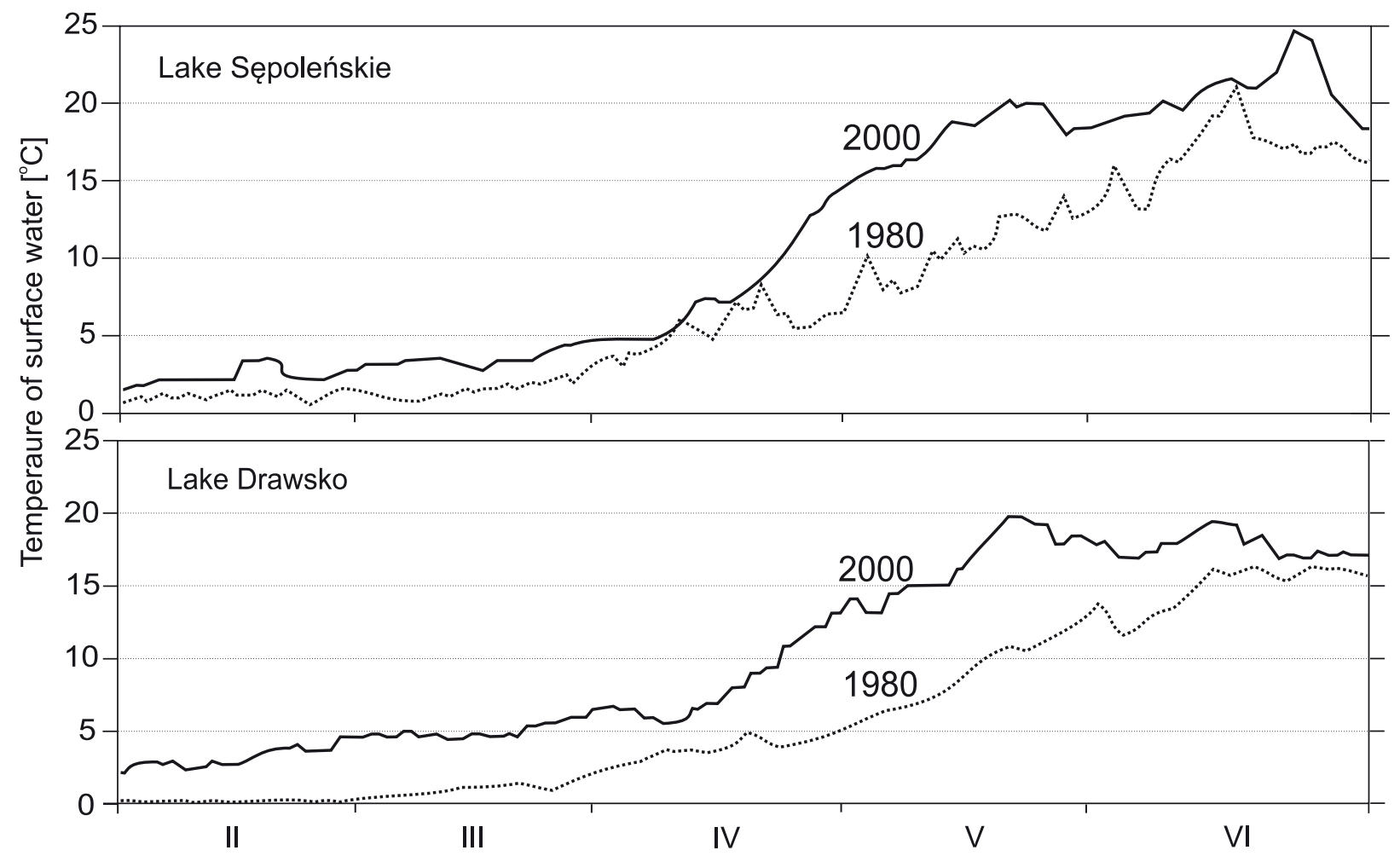

Fig. 3. The course of surface water temperature values in selected lakes in 1980 and 2000 (from February to July)

The difference in the dates when the selected threshold values of SWT were recorded between the cool spring of 1980 and the warm spring of 2000 is relatively large. The greatest variations occurred in the second phase of spring warming, which comprises the period with water temperature in the range $10-15^{\circ} \mathrm{C}$ (Skowron 2008). In 1980 the temperature of $15^{\circ} \mathrm{C}$ was registered as late as 7 th June and in 2009 it was noted 
as early as 2nd May. In the Greater Poland and Masurian Lakelands these differences are even more significant and exceeded 37 days (Table 2).

The average dates when the threshold values of the SWT were recorded showed noticeable differences between the individual regions of the Polish Lowland. The dates with the temperature of $4^{\circ} \mathrm{C}$ were noted earliest in mid and late March in the lakes of the Greater Poland Lakeland, in the coastal lakes, and in the shallow water bodies of the East-Pomerania Lakeland (Lake Jeziorak). The surface water temperature of $4^{\circ} \mathrm{C}$ was recorded latest in the lakes of the Suwałki Lakeland. On average, it was noted around 11th April. Lake Morskie Oko located high up in the Polish mountains is a special example: the SWT of $4^{\circ} \mathrm{C}$ was recorded as late as 23rd May.

On the other hand, the dates with the surface water temperature of $10^{\circ} \mathrm{C}$ were recorded in the first ten days of May on average. This temperature was noted earliest at the end of April in the shallow lakes (Sławskie - 26th April, Łebsko, Jeziorak and Śniardwy - 29th April), and latest in the deepest lakes (Hańcza 20th May, Drawsko - 19th May and Raduńskie Górne - 16th May). On average, it stayed for 34 days after the dates with the temperature of $4^{\circ} \mathrm{C}$, and the time difference between the two dates decreased eastwards, reaching 28 days in the east of Poland, but as many as 44 days in the Greater Poland Lakeland. These disproportions prove various dates when thermal spring enters the northern areas of Poland.

On average, from late May the surface water temperature values of most Polish lakes stay beyond the threshold value of $15^{\circ} \mathrm{C}$. Yet the dates when the SWT equalled $15^{\circ} \mathrm{C}$ were also different with respect to various lakes. This temperature was observed earliest in shallow lakes: Sławskie and Śniardwy - 17th May, Sępoleńskie - 20 May, and latest in deep lakes: Drawsko - 8 June, Hańcza and Raduńskie Górne - 6 June). The differences with respect to the lakes located most distantly from one another amounted merely to 10 days. In this case mainly the depth and the lake's mixing type determined the time differences (Table 3 ). In the period of the late phase of spring warming the biggest daily increases in surface water temperature were recorded. They exceeded $2.5^{\circ} \mathrm{C}$ per ten days (Table 4 ). The maximum ten-day increases in temperature were recorded on average in early and mid May (Ełckie $-3.38^{\circ} \mathrm{C}$, Rajgrodzkie $-3.37^{\circ} \mathrm{C}$, and Selmęt Wielki $-3.28^{\circ} \mathrm{C}$ ).

Table 2. The average dates when the surface water temperature values exceeded temperature values characteristic of the spring period in 1980 and 2000 (the number of lakes given in brackets)

\begin{tabular}{|c|c|c|c|c|c|c|}
\hline \multirow{2}{*}{$\begin{array}{c}\text { Lakeland } \\
\text { (number of lakes) }\end{array}$} & \multicolumn{3}{|c|}{1980} & \multicolumn{3}{|c|}{2000} \\
\hline & $4^{\circ} \mathrm{C}$ & $10^{\circ} \mathrm{C}$ & $15^{\circ} \mathrm{C}$ & $4^{\circ} \mathrm{C}$ & $10^{\circ} \mathrm{C}$ & $15^{\circ} \mathrm{C}$ \\
\hline Greater Poland (3) & $02-04$ & $16-05$ & $06-06$ & $19-03$ & $22-04$ & $30-04$ \\
\hline Pomeranian (10) & $15-04$ & $14-05$ & $07-06$ & $22-03$ & $21-04$ & $06-05$ \\
\hline Masurian (11) & $18-04$ & $20-05$ & $06-06$ & 01-04 & $19-04$ & $28-04$ \\
\hline Suwałki (4) & 23-04 & $30-05$ & $09-06$ & $08-04$ & $22-04$ & 01-05 \\
\hline Mean & $15-04$ & $18-05$ & $07-06$ & $27-03$ & $21-04$ & $02-05$ \\
\hline
\end{tabular}

Table 3. The mean dates when the characteristic values of SWT were recorded in the lakes in selected regions in Poland during the spring warming in the years 1971-2005 (the author's calculations based on the data obtained from the Institute of Meteorology and Water Management)

\begin{tabular}{|c|c|c|c|c|}
\hline Lakeland (number of lakes) & $2^{\circ} \mathrm{C}$ & $4^{\circ} \mathrm{C}$ & $10^{\circ} \mathrm{C}$ & $15^{\circ} \mathrm{C}$ \\
\hline Greater Poland (3) & 23-02 & $17-03$ & $30-04$ & $20-05$ \\
\hline Pomeranian (7) & $12-03$ & $4-04$ & $9-05$ & $29-05$ \\
\hline Coastal lakes (3) & 4-03 & 23-03 & $1-05$ & $29-05$ \\
\hline East Pomeranian (3) & $8-03$ & $29-03$ & $1-05$ & $21-05$ \\
\hline Masurian (8) & $15-03$ & $4-04$ & $4-05$ & $23-05$ \\
\hline Suwałki (4) & $19-03$ & $11-04$ & $9-05$ & $27-05$ \\
\hline Lake Białe (Łęczna-Włodawa Lakeland) ${ }^{1)}$ & $17-03$ & $4-04$ & $3-05$ & $19-05$ \\
\hline Lake Morskie Oko (Tatra Mountains) ${ }^{1)}$ & $12-05$ & 23-05 & $8-07$ & - \\
\hline
\end{tabular}

1) - data for period 1971-1995 
Table 4. The mean ten-day values of surface water temperature (SWT) in lakes in selected regions in Poland from March to June in the years 1971-2005 (the author's calculations based on the data obtained from the Institute of Meteorology and Water Management)

\begin{tabular}{|c|c|c|c|c|c|c|c|c|c|}
\hline \multirow{2}{*}{ Lakeland (number of lakes) } & \multicolumn{3}{|c|}{ March } & \multicolumn{3}{|c|}{ April } & \multicolumn{3}{|c|}{ May } \\
\hline & I & II & III & I & II & III & I & II & III \\
\hline Greater Poland (3) & 2.7 & 3.5 & 4.5 & 6.0 & 7.3 & 9.3 & 11.7 & 14.2 & 16.1 \\
\hline Pomeranian (7) & 1.7 & 2.3 & 3.1 & 4.3 & 5.4 & 7.2 & 9.5 & 12.2 & 14.4 \\
\hline Coastal lakes (3) & 2.1 & 2.9 & 3.9 & 5.6 & 6.8 & 8.8 & 10.9 & 13.0 & 14.4 \\
\hline East-Pomeranian (3) & 1.7 & 2.4 & 3.4 & 5.0 & 6.4 & 8.7 & 11.3 & 14.1 & 16.0 \\
\hline Masurian (8) & 1.5 & 1.9 & 2.8 & 4.2 & 5.6 & 7.8 & 10.7 & 13.5 & 15.5 \\
\hline Suwałki (4) & 1.2 & 1.5 & 2.3 & 3.4 & 4.7 & 6.8 & 9.4 & 12.1 & 14.7 \\
\hline Lake Białe (Łęczna-Włodawa Lakeland) ${ }^{1)}$ & 1.4 & 1.7 & 2.9 & 4.2 & 5.8 & 8.2 & 10.9 & 14.4 & 16.7 \\
\hline Lake Morskie Oko (Tatra Mountains) $)^{1)}$ & 1.0 & 1.0 & 1.0 & 1.1 & 1.2 & 1.3 & 1.8 & 3.1 & 4.7 \\
\hline
\end{tabular}

1) data for period 1971-1995

In the middle of April, i.e. approximately 30 days after the ice cover break-up, the deepest lakes were the coldest (Hańcza $-3.2^{\circ} \mathrm{C}$ and Wdzydze Południowe $4.2^{\circ} \mathrm{C}$ ), whereas the shallowest lakes were the warmest (Sławskie $-8.2^{\circ} \mathrm{C}$, Jamno $-7.4^{\circ} \mathrm{C}$ and Gopło $-7.3^{\circ} \mathrm{C}$ ). At the end of May, once the thermal stratification of water was well defined (Skowron 2011a), the highest values of surface water temperature were recorded in the shallowest lakes (Jeziorak $-16.6^{\circ} \mathrm{C}$, Sławskie $16.5^{\circ} \mathrm{C}$, Śniardwy $-16.4^{\circ} \mathrm{C}$ and Sępoleńskie $-16.3^{\circ} \mathrm{C}$ ), while the lowest values were registered in the deepest lakes (Hańcza $-12.4^{\circ} \mathrm{C}$, Raduńskie Górne $-13.0^{\circ} \mathrm{C}$ and Drawsko $\left.-13.5^{\circ} \mathrm{C}\right)$. Therefore, during the entire spring warming period, i.e. from the beginning of March to the end of May, the surface water temperature in the lakes was determined mainly by the lake's depth and volume of retained water as well as mixis.

Course of the thermal stratification of water. The course of the surface water temperature in the lakes is reflected by main changes in the thermal structure of water, which relate to the morphometric properties of the water bodies, their hydrological properties, mixis and trophic state (Patalas 1960; Skowron 2011a).

The formation of the thermal stratification of water in the lakes was clearly diversified during the spring warming period. The detailed measurements were carried out using thermal gradient sensors. The highest surface water temperature $(0.5 \mathrm{~m})$ was observed in Lakes Bachotek and Starokiejkuckie, whereas Lake Ostrowite was considerably cooler by approximately $1.2-1.5^{\circ} \mathrm{C}$. The differences in the surface water temperature among the lakes rarely exceeded $2^{\circ} \mathrm{C}$ during the period from mid-April to the end of May. On the other hand, the signs of the stable thermal strati- fication were observed when the surface water temperature stayed above $7-8^{\circ} \mathrm{C}$.

The examinations of the vertical distribution of water temperature in the different lakes of the Polish Lowland in the first phase of spring warming showed a homogeneous arrangement of water temperature, with slightly warmer littoral parts of the lake. The differences in water temperature between the open part of the lake and the littoral part of the lake rarely exceeded $1-1.5^{\circ} \mathrm{C}$.

Very valuable observation material was obtained during the synchronous measurements carried out in several water bodies in three different years and terms of spring warming. They proved considerable differences in the course of water temperature and the development degree of the thermal structure in the studied lakes at that time.

The examinations conducted a month after the ice cover break-up proved that the surface water temperature amounted to approx. $3.2-3.8^{\circ} \mathrm{C}$ in March (2022.03) 1996, approx. $10^{\circ} \mathrm{C}$ in April (22-24.04) 2003, and ranged from 10 to $12^{\circ} \mathrm{C}$ in May (7-9.05) 2000 (Table 5). The differences in the surface water temperature reached $14.5^{\circ} \mathrm{C}$ and the differences between the surface layer and the bottom layer exceeded $10.5^{\circ} \mathrm{C}$. Therefore, water temperature was the derivative of the course of the thermal winter on the one hand, and the arrival date of the thermal spring on the other hand.

The results of the measurements indicated beyond all doubt that, regardless of the lake's area, depth ratio, mixing character and the disappearance of ice phenomena, the diversified course of water temperature in the lakes during spring warming is determined by the coldness degree of the water mass directly be- 
Table 5. Location, morphometric data and the mean parameters of the thermal structure of waters in the lakes of the Polish Lowland during various periods of spring warming in selected years (extreme values given in brackets)

\begin{tabular}{|c|c|c|c|c|c|c|c|}
\hline $\begin{array}{c}\text { Date of } \\
\text { measurements }\end{array}$ & $\begin{array}{l}\text { Average area of } \\
\text { the lakes in ha } \\
\text { (extreme values) }\end{array}$ & $\begin{array}{c}\text { Mean maximum } \\
\text { depth in } \mathrm{m} \\
\text { (extreme values) }\end{array}$ & $\begin{array}{l}\text { Mean temperature } \\
\text { near the surface } \\
\text { (extreme values) }\end{array}$ & $\begin{array}{l}\text { Mean temperature } \\
\text { of the water } \\
\text { near the bottom } \\
\text { (extreme values) }\end{array}$ & $\begin{array}{l}\text { Mean difference in } \\
\text { water temperature } \\
\text { surface-bottom } \\
\text { (extreme values) }\end{array}$ & $\begin{array}{l}\text { Mean thermal } \\
\text { stratification } \\
\text { coefficient } \mu \\
\text { (extreme values) }\end{array}$ & $\begin{array}{l}\text { Average position } \\
\text { of the upper limit } \\
\text { of the thermocline } \\
\text { (extreme values) }\end{array}$ \\
\hline $20-22.03 .2000$ & $\begin{array}{c}133.9 \\
(5.5-1097.5)\end{array}$ & $\begin{array}{c}15.6 \\
(1.7--46.0)\end{array}$ & $\begin{array}{c}3.6 \\
(1.9-5.5)\end{array}$ & $\begin{array}{c}3.4 \\
(1.9-5.1)\end{array}$ & $\begin{array}{c}0.1 \\
(0.0-0.4)\end{array}$ & $\begin{array}{c}0.976 \\
(0.937-1.000)\end{array}$ & lack of thermocline \\
\hline $22.03-4.04 .2003$ & $\begin{array}{c}128.9 \\
(3.7-671.0)\end{array}$ & $\begin{array}{c}17.0 \\
(3.7-54.5)\end{array}$ & $\begin{array}{c}10.1 \\
(7.5-13.1)\end{array}$ & $\begin{array}{c}6.5 \\
(3.7-12.0)\end{array}$ & $\begin{array}{c}3.0 \\
(0.1-6.9)\end{array}$ & $\begin{array}{c}0.796 \\
(0.542-0.996)\end{array}$ & $\begin{array}{c}2.7 \\
\text { (lack of } \\
\text { thermocline }-5 \text { ) }\end{array}$ \\
\hline $7-9.05 .1996$ & $\begin{array}{c}148.2 \\
(12.5-1012.5)\end{array}$ & $\begin{array}{c}20.4 \\
(2.6-106.1)\end{array}$ & $\begin{array}{c}11.0 \\
(3.9-16.4)\end{array}$ & $\begin{array}{c}6.1 \\
(2.4-13.2)\end{array}$ & $\begin{array}{c}4.9 \\
(0.0-10.8)\end{array}$ & $\begin{array}{c}0.722 \\
(0.369-1.006)\end{array}$ & $\begin{array}{c}4.2 \\
\text { (lack of } \\
\text { thermocline -10) }\end{array}$ \\
\hline
\end{tabular}

fore icing and mainly by meteorological conditions in the period from February to June.

The normal (anothermal) stratification in lakes occurs when the surface water temperature (to $1 \mathrm{~m}$ ) exceeds $7-8^{\circ} \mathrm{C}$. Constant warming of water and mixing in a short time causes the formation of an overheated water layer reaching to 2,3, and sometimes more metres and a thermocline of a low thickness. With time the metalimnion deepens faster causing the development of a clear thermal stratification with a steeply marked layer of a thermocline and a still cold hypolimnion layer. The character of the changes in the thermal structure of the lakes marks itself most distinctly when the surface water temperature exceeds $12-13^{\circ} \mathrm{C}$, and the bottom layers are still cold $\left(3-5^{\circ} \mathrm{C}\right)$. This fact is proven by considerable differences of temperature between the one-metre surface layer and the bottom layer, which increase from $2-3^{\circ} \mathrm{C}$ in mid April to over $6-7^{\circ} \mathrm{C}$ in early and mid May. Simultaneously, the thermal stratification coefficient rises respectively from 0.977 in March, through 0.796 in April to 0.772 in May (Table 5).

The measurements taken in Lake Bachotek indicated that in the initial phase of the thermal stratification of water (the first half of May) there were distinct differences in the location of the metalimnion. Its upper limit was found from 2.5 to $6 \mathrm{~m}$ (Skowron 2011b). Similar results were obtained in Lake Śremskie. They indicated stabilization of the developed thermal layers at the turn of May and June, when the surface water temperature reached $15^{\circ} \mathrm{C}$. From the beginning of June further deepening of the lower limit of the metalimnion was observed, which was still more stable than the upper limit. These processes are confirmed by the courses of the mean water temperature in the lakes located in the Brodnica Lakeland in the spring periods of 2009 and 2010 (Fig. 4).
However, it must be remembered that the thermal stratification of water during the period of spring warming is often destroyed by wind, and the position of the top and bottom limit of the matalimnion may vary even up to $1.5-2.0 \mathrm{~m}$ (Fig. 5 and 6). This was proven by the measurements conducted in other lakes (Gopło, Bachotek, Hańcza, Popielewskie, Zbiczno, Skulskie) (Skowron 1999; 2007b).

The differences in the mean water temperature in the surface layer $(0-1 \mathrm{~m})$ amounted to $4.6^{\circ} \mathrm{C}$, with the average value of $2.0^{\circ} \mathrm{C}$. The mean gradient in the deepest parts of the lake was rarely lower than $1.5^{\circ} \mathrm{C}$ $\mathrm{m}^{-1}$. Considerably greater gradient values were observed directly after intense wind mixing (Okulanis 1981; Skowron 1999).

\section{Conclusion}

In the annual course of water temperature in lakes, the spring is a period in which all the characteristic processes shaping the thermal regime of lakes occur. Firstly, there is a change in the resultant direction of the exchange of heat between the lake and the atmosphere, which allows for a relatively fast increase in heat resources and water temperature. Secondly, homogeneous distribution (spring homothermy) develops then and is accompanied by convective mixing of the entire water mass and oxygenation of the deeper (often deoxygenated) layers.

The conducted investigations into the changes in water temperature in Polish lakes during spring warming showed the specificity of the spring phase of the annual thermal cycle of the lakes, and above all, they documented the time and the spatial diversity of parameters and their describing indicators.

The data for the period 1971-2005 indicate that 

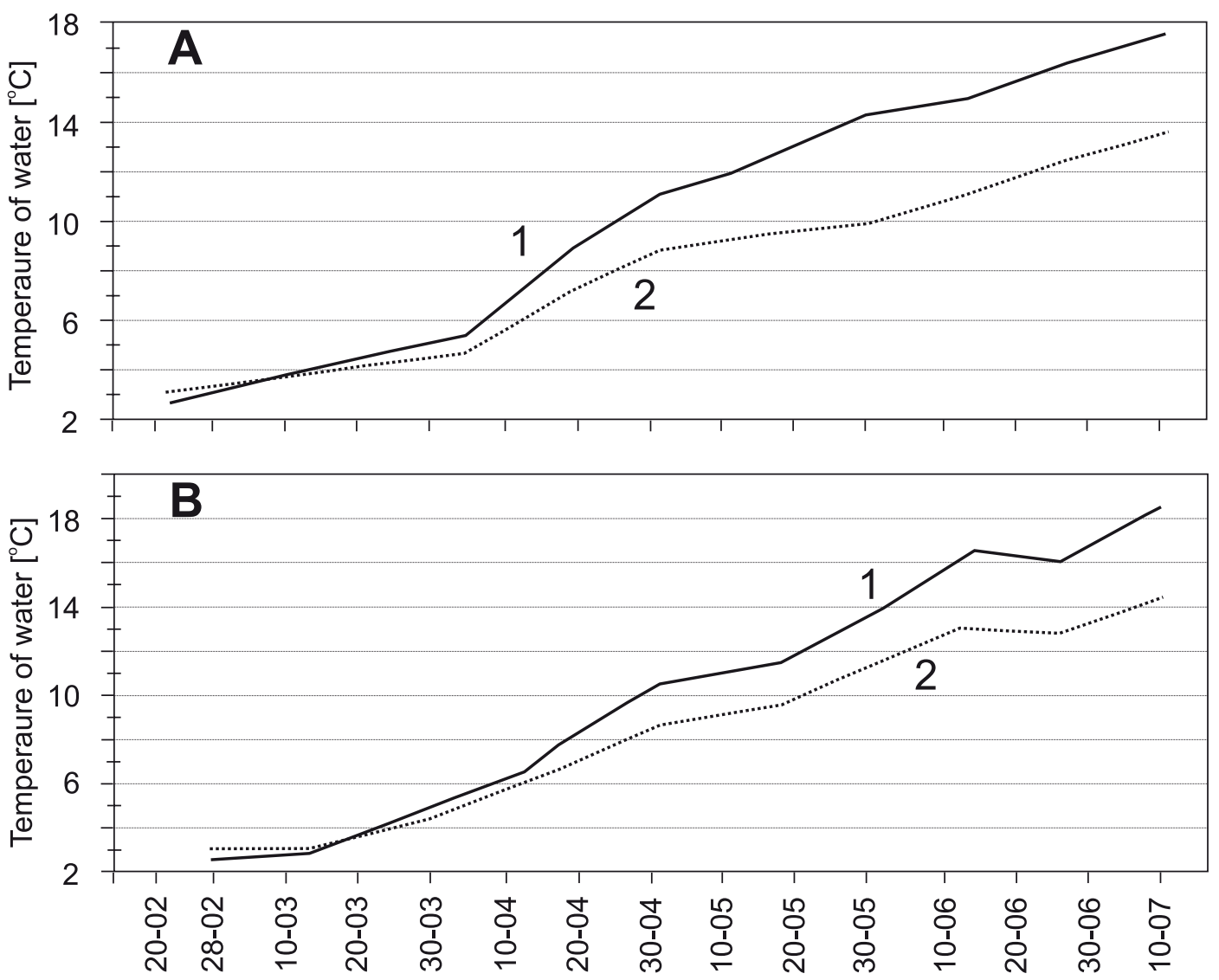

Fig. 4. The course of mean water temperature in Lake Bachotek (1) and Lake Łąkorz (2) in 2009 (A) and 2010 (B)

the dates with the recorded threshold values of the surface water temperature also vary significantly in the individual years of the analysed period. With average conditions, the mean surface water temperature of $4^{\circ} \mathrm{C}$ was observed earliest in the Greater Poland Lakeland (Sławskie - 13th March and Gopło - 17th March), and latest in the deep lakes, such as Wdzydze - 11th April, Hańcza - 24th April. Lake Morskie Oko, located high up in the mountains, is an exception. The temperature of $4^{\circ} \mathrm{C}$ was recorded as late as $23 \mathrm{rd}$ May on average (Choiński 2010). The state of homothermy occurred most frequently 18-24 days after the entire ice cover had disappeared, yet under 16-18 days with respect to the shallow lakes, and more than 24 days with respect to the deep lakes. The water temperature of $10^{\circ} \mathrm{C}$ was registered earliest in the shallow lakes at the end of April (Sławskie - 25th April, Jeziorak and Sniardwy 28th April), and latest in the deepest lakes, such as Hańcza - 20th May, Raduńskie Górne - 15th May, and Wdzydze Południowe - 12th May. A similar trend was also observed with the record of the temperature value of $15^{\circ} \mathrm{C}$.
The period of spring warming was characterized by the considerable increased pace in the surface water temperature in the lakes. Once the entire ice cover had disappeared completely (the second week of March on average) there was an evident increase in water temperature. The greatest increases took place most frequently in early and mid May, when the values were over $2.5^{\circ} \mathrm{C}$ per ten days. The course of the mean ten-day increases in temperature proves that the changes in temperature were of considerable dynamics in the individual years. This is confirmed by the indexes of the standard deviation, which took on the highest values (Skowron 2011a).

Most frequently after the surface water temperature exceeds the value of $6-8^{\circ} \mathrm{C}$, regular microstratification is formed (Lange 1986; Skowron 2011). The formation of the regular micro-stratification may be easily modified by wind, which consequently leads to its faster disappearance (Skowron 2011b).

The examinations of water temperature showed that the dates of the ice cover break up and the course of the meteorological conditions during spring warm- 

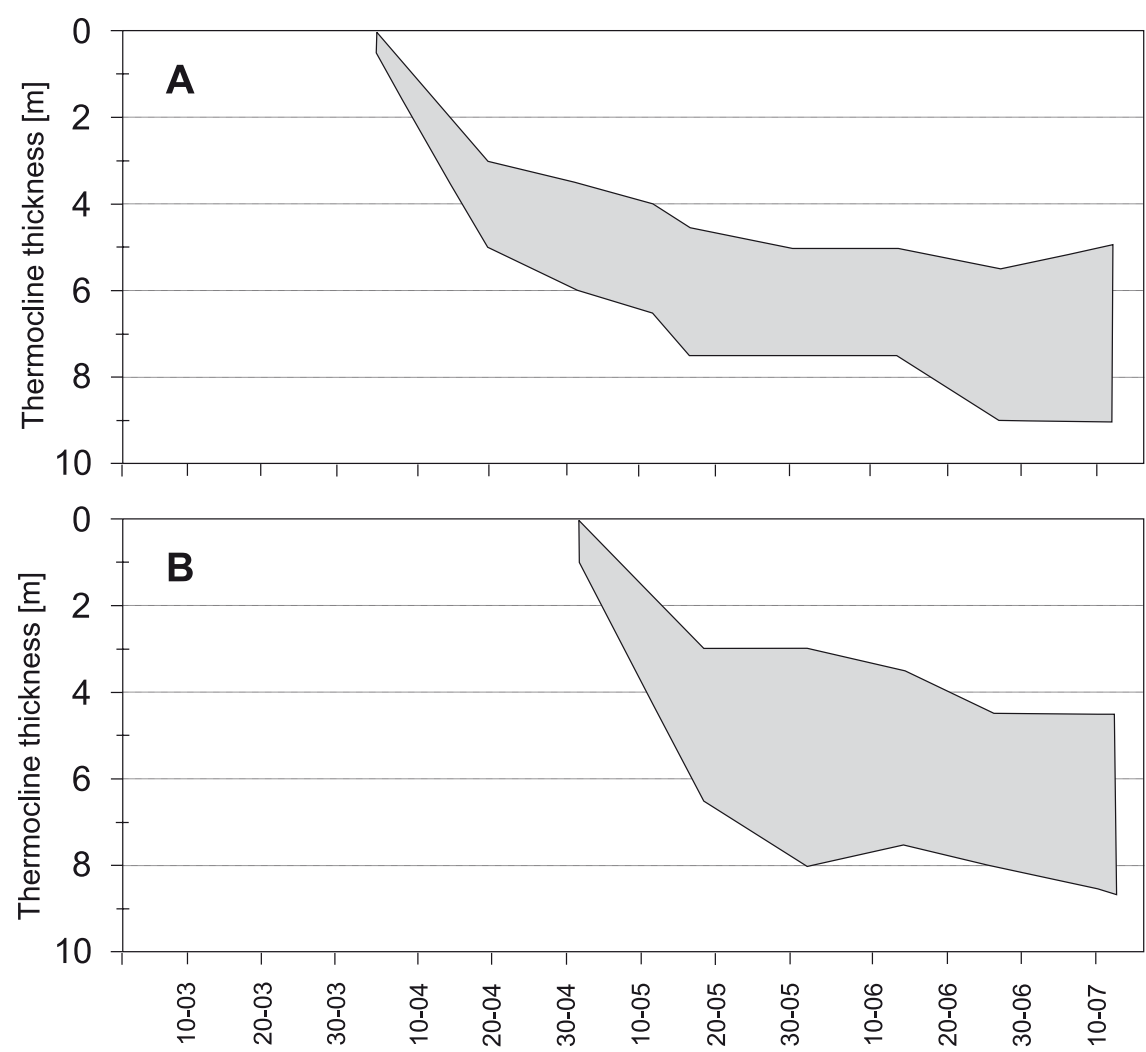

Fig. 5. The course of the metalimnion formation on Lake Bachotek in 2009 (A) and 2010 (B)
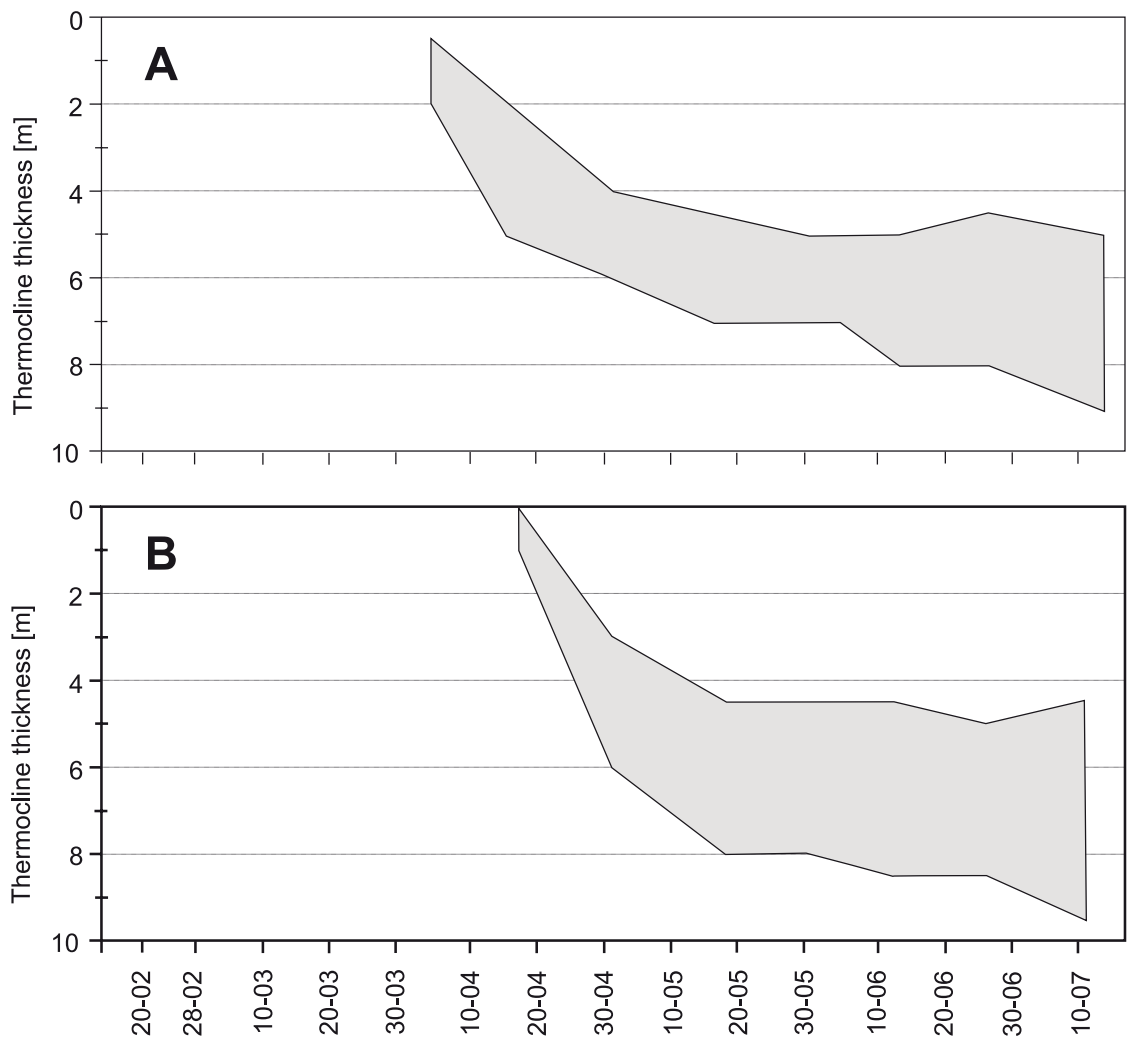

Fig. 6. The course of the metalimnion formation in Lake Zbiczno in 2009 (A) and 2010 (B) 
ing had direct influence upon the water temperature in the hypolimnion. The measurements conducted in the lakes of the Polish Lowland indicate that the temperature values in the bottom layers during the greatest heat resources in the lakes (mid August) varied significantly in the individual years. The absolute interyear differences in the hypolimnion temperature are lowest in the deepest lakes, and are as follows: Gopło $(15 \mathrm{~m})-3.9^{\circ} \mathrm{C}$, Bachotek $(25 \mathrm{~m})-3.6^{\circ} \mathrm{C}$, Miedwie $(40$ $\mathrm{m})-2.6^{\circ} \mathrm{C}$, Drawsko $(70 \mathrm{~m})-1.2^{\circ} \mathrm{C}$, and Hańcza $(100$ $\mathrm{m})-0.8^{\circ} \mathrm{C}$.

The course of the surface water temperature clearly presents a positive trend for all the lakes in the period from early January to early June. The highest values are recorded in the period March-May (0.05$\left.0.06^{\circ} \mathrm{C} \mathrm{yr}^{-1}\right)$. This is also confirmed by the studies conducted in the lakes of Belarus, Lithuania and the European part of Russia (Bukantis et al. 2001; Lemeshko, Borzenkova 2001; Gronskaya et al. 2001; Jefremova and Palshin 2003; Pernaravičiūte 2004; Danilovish 2005; Naumenko et al. 2006).

Shorter periods with ice phenomena, which result from warming and especially in winter, have an obvious influence upon the course of the surface water temperature. This mainly involves earlier disappearance or shorter duration of ice cover at the level of 0.4-0.6 $\mathrm{d} \mathrm{yr}^{-1}$ and 0.5-0.7 $\mathrm{d} \mathrm{yr}^{-1}$ respectively (Skowron 2011). These conclusions correspond to the viewpoints of other researchers (Palecky and Barry 1986; Magnuson et al. 2000; Kilkus and Valiuskevicius 2001; Karentikov, Naumenko 2008).

Climate warming also had an impact upon the changes in the vertical thermal structure of the lakes located in the Polish Lowland. The changes in the course of ice phenomena and the surface water temperature lead to the development of the spring and summer thermal stratification of water in the lakes. For instance, the effects of climatic changes can be seen in the earlier occurrence of the temperature of $10^{\circ} \mathrm{C}$ in the spring period, and clear dependency between the duration of the period with the temperature of $4^{\circ} \mathrm{C}$ and the NAO index (Gronskaya et al. 2001). The investigations conducted in the State of Wisconsin (USA) confirmed the earlier occurrence of thermal stratification and the increase in the temperature of the epilimnion, as well as the elongation of the period with thermal stratification (De Stasio et al. 1996). The studies carried out in 180 lakes located in Poland prove the increase in thermal gradients, shallowing positions of the thermocline, and rising differences between the epi- and hypolimnion during the summer stagnation (Skowron 2011a).

The spring warming period defined in such a way lasted in the analysed lakes for 70.4 days on average (i.e. $19 \%$ of the duration of the annual thermal cycle of the lakes), whereas its first phase only 15.1 days ( $4 \%$ of the annual cycle). In the deepest lakes the duration of the early spring warming lengthens to over 20 days (Lake Hańcza - 36 days).

\section{References}

Choiński A., 2007, Limnologia fizyczna Polski (Physical limnology of Poland), Wyd. Nauk. UAM, Poznań, p. 547.

Choiński A., Kanikowski J., 2004, Fluctuations in water temperature of Lake Zamkowe, Limnol. Rev. 4: 33-44.

Choiński A., 2010, Termika wód Morskiego Oka w 2007 roku na podstawie rejestracji gradientowej sondy termicznej (Temperature of waters of the Lake Morskie Oko in 2007 based on the registration of the gradient thermal sonde) [Abstract], [in:] Machula S., Kubiak J. (eds), Naturalne i antropogeniczne przemiany jezior (Anthropogenic and natural transformations of lakes), XV Ogólnopolska Konferencja Limnologiczna, Materiały konferencyjne, Szczecin: 11 (in Polish).

Chojnowski S., 1967, Uwagi o zmianach temperatury wody jeziornej (Remarks on temperature variations in lake water), Wiad. Służby Hydrol. Meteor. 3(1): 53-59 (in Polish, English summary).

Chomskis V., 1969, Dinamika i termika małych ozer (Dynamics and thermic regime of small lakes), Izd. Mintis, Vilnius, p. 204 (in Russian).

Glazik R., Marszelewski W., Skowron R., 2006, Selected problems of registration of vertical distribution of water temperatures in lakes, Limnol. Rev. 6: 103-110.

Janiec B., Turczyński M., 1988, Wiosenno-letnia faza cyklu termicznego najgłębszych jezior Pojezierza LeczyńskoWłodawskiego (The spring-summer phase of thermal cycle of the deepest lakes in the Łęczna-Włodawa Lakeland), Badania Hydrograficzne w Poznawaniu Środowiska 1, Wyd. UMCS, Lublin: 59-70 (in Polish).

Jędrasik J., 1985, Uwarunkowania cykli termicznych w jeziorach (Conditions determining thermal cycles in lakes), Zesz. Nauk. Wydz. BiNoZ UG, Geografia 14: 45-56 (in Polish, English summary).

Okulanis E., 1981, Studium limnologiczne Jezior Raduńsko-Ostrzyckich (Limnological studies of RaduńskoOstrzyckie Lakes), GTN, Gdańsk, p. 110 (in Polish).

Patalas K., 1960, Mieszanie wody jako czynnik określający intensywność krążenia materii $\mathrm{w}$ różnych morfologicznie jeziorach okolic Węgorzowa (Mixing of wind as a factor determining the intensity of circulation of matter in morphologically different lakes surrounding Węgorzewo), Rocz. Nauk Rol. B 77(1): 223-242 (in Polish, English summary). 
Skowron R., 1999, Letnia stratyfikacja termiczna wody w jeziorze Hańcza (Thermal stratification of water in Lake Hańcza in summer), Acta Univ. Nicol. Copern. Geogr. 29: 247-256 (in Polish, English summary).

Skowron R., 2001, Surface water thermal seasons in Polish lakes, their distribution and spatial differentation, Limnol. Rev. 1: 251-263.

Skowron R., 2003, Ice sheet in the lakes of the Polish Lowland. Distribution, differences and trends, Limnol. Rev. 3: 205-212.

Skowron R., 2006, Differences in thermal and ice regimes formation in lakes Gopło and Bachotek, Limnol. Rev. 6: 255-262.

Skowron R., 2007a, Roczny cykl temperatury wody powierzchniowej $\mathrm{w}$ jeziorach na Niżu Polskim i jego zmienność (Annual cycle of surface water temperature in the lakes in the Polish Lowland and its changeability), [in:] Michalczyk Z. (ed.), Obieg wody w środowisku naturalnym i przekształconym (Water circulation in natural and transformed environment), Badania Hydrograficzne w Poznawaniu Środowiska 8, Wyd. UMCS, Lublin: 452-461 (in Polish, English summary).

Skowron R., 2007b, The thermocline layer in the thermal water structure of selected Polish lakes, [in:] Kubiak J., Bajkiewicz-Grabowska E. (eds), Anthropogenic and natural transformations of lakes. Vol. 1, Agricultural University of Szczecin, Polish Limnological Society, Szczecin: 115-118.
Skowron R., 2008, Thermal conditions of water in lakes during winter stagnation - selected poblems, [in:] Bajkiewicz-Grabowska E., Borowiak D. (eds), Anthropogenic and natural transformations of lakes. Vol. 2, Wyd. KLUG-PTLim, Gdańsk: 187-190.

Skowron R., 2011a, Zróżnicowanie i zmienność wybranych elementów reżimu termicznego $\mathrm{w}$ jeziorach na Niżu Polskim (The differentiation and the changeability of chosen of elements the thermal regime of water in lakes on Polish Lowland), Wyd. UMK, Toruń, p. 345 (in Polish, English summary).

Skowron R., 2011b, Kształtowanie się temperatury wody $\mathrm{w}$ okresie wiosennego nagrzewania $\mathrm{w}$ wybranych jeziorach $\mathrm{w}$ Polsce (Course of water temperature in the spring season in the selected Polish lakes), [in:] Marszelewski W. (ed.), Anthropogenic and natural transformations of lakes. Vol. 5, PTLim-UMK, Toruń: 145-155 (in Polish, English summary).

Tikhomirov A.I., 1982, Termika krupnych ozer (Thermal regime of large lakes), Izdat. Nauka, Leningrad, p. 208 (in Russian). 